\title{
Effects of Plant Spacing and Mulching on Yield and Profitability of Lettuce (Lactuca sativa L.)
}

\author{
M. MONiruZZAMaN* \\ Agricultural Research Station, Bangladesh Agricultural Research Institute, Raikhali, Chandraghona, \\ Rangamati Hill District, Bangladesh
}

Received 13 October 2004; received in revised form 24 August 2005; accepted 22 June 2006

\begin{abstract}
A field experiment with three levels of spacing $(40 \times 20 \mathrm{~cm}, 40 \times 30 \mathrm{~cm}$ and $40 \times 40 \mathrm{~cm})$ and two levels of mulching (mulch and non-mulch) was conducted to find out the effect of plant spacing and mulching on yield and profitability of lettuce cv. Green Wave at the Agricultural Research Station, Raikhali, Rangamati Hill District for the two consecutive years during 1999-'00 and 2000-'01. Plant spacing, mulching and their interaction showed significant effect on yield and yield components of lettuce. The highest fresh yield of lettuce was obtained from the closest spacing $(40 \times 20 \mathrm{~cm})$ that was statistically similar to that recorded of medium spacing $(40 \times 30 \mathrm{~cm})$ during both the years. Significantly higher fresh yield of lettuce was obtained from the mulched plants than that of unmulched plants. The highest yield (25.9 tha in 1999-'00 and 28.3 t/ha in 2000-'01 with an average of $27.10 \mathrm{t} / \mathrm{ha}$ ) was observed in the spacing of $40 \times 20 \mathrm{~cm}$ with mulch, which was statistically at par with the spacing of $40 \times 30 \mathrm{~cm}$ with mulch. The results also revealed that higher Gross Return (Tk. $216,800.00)$ was obtained from the closest spacing in combination with mulch followed by medium spacing $(40 \times 30 \mathrm{~cm})$ with mulch (Tk. 210, 160.00). The treatment combination of $40 \times 30 \mathrm{~cm}$ spacing and mulching gave the highest benefit cost ratio (8.84). But the benefit cost ratio (4.22) from the treatment combination of $40 \times 20 \mathrm{~cm}$ spacing and mulching was less due to the involvement of higher seedling cost.
\end{abstract}

Key words: Spacing, mulching, lettuce, yield, profitability.

\section{INTRODUCTION}

Lettuce (Lactuca sativa $\mathrm{L}$ ) is an important leafy salad vegetable, rich in vitamins and minerals, that is mainly grown in cool season of the year in tropical and sub-tropical countries including Bangladesh (Rahman et al., 1997). Lettuce is a newly introduced crop in Bangladesh and its production package is almost unknown. To achieve optimum production the management of this vegetable, such as spacing and mulching are very important. As there is a great difference between the tropical and temperate environments in terms of temperature, light and humidity, there may be some differences in management practices including planting density and mulching. Among the factors that affect yield and quality of lettuce, population or plant density is one of the most important elements. Lettuce yield usually varies with different plant densities. Spacing influences average fresh weight, number of heads, and yield at harvest (Adu-Sankode, 1980; El-

* Corresponding Author: SO (Hort.), ARS, Bari, Raikhali, Chandraghona, Rangamati Hill District-4531.

(C) 2006, School of Agriculture and Rural Development, Bangladesh Open University. All rights reserved 
Shal et al., 1986; Eyisok et al., 1996). Suitable plant spacing can lead to optimum yield whereas too high or too low plant spacing could result in relatively lower yield and quality (Kobryn, 1987). The plant spacing recommended for lettuce cultivation cited in various books, annual reports and journals generally range from 20 to $45 \mathrm{~cm}$ between plants and 30 to $50 \mathrm{~cm}$ between rows (Anon., 2000; Bose and Som, 1986; Rahman et al., 1997; Rashid, 1999; Thomson, 1972). Based on this conditions, three plant spacings are chosen for the experiment.

Lettuce is a cool season crop. The optimum mean temperature range for excellent growth and good quality of lettuce is $15-25^{\circ} \mathrm{C}$ and temperature above $25^{\circ} \mathrm{C}$ accelerates seed stalk and reduces the quality of leaves (Rashid, 1999). It is evident that high air temperature causes high soil temperature, which retards root growth and affects the uptake of water and nutrients and photosynthesis that consequently results in stunted plant growth and mortality (Firoz et al., 2000). One way of solving this problem is mulching, which has various effects on the soil and plants. Mulching helps to maintain uniform temperature, controls weed and the draining of fertilizers, conserves soil moisture and improves irrigation efficiency (AVRDC 1990; Benoit and Ceustermans 1996). Moisture distribution in the upper soil layer is more uniform in comparison with non-mulched soil and more roots developed in that layer which usually has richer nutrients and useful microorganisms (Knavel and Mohr, 1967; Lippert et al., 1964). Rice straw is always available in the farmer's field and when this indigenous material is used as mulch, it enhances vegetative growth by reducing soil moisture depletion and temperature (Kuo and Tsay, 1981). In view of the above facts, the present investigation was carried out to find out the optimum plant spacing and effect of mulching to achieve better yield and profitability of lettuce.

\section{MATERIALS AND METHODS}

The experiment was conducted from November 1999 to February 2001 at the Agricultural Research Station, Raikhali, Rangamati Hill District. The soil was sandy clay loam with $5.4 \mathrm{pH}$ and contained $1.48 \%$ organic matter. The total nitrogen, available phosphorus and exchangeable potassium were $0.078 \%, 8.0 \mu \mathrm{g} / \mathrm{g}$ and $0.17 \mathrm{meq} / 100 \mathrm{~g}$ soil, respectively. The treatments of the experiment comprised of three different plant spacing $(40 \times 20 \mathrm{~cm}, 40 \times 30 \mathrm{~cm}$ and $40 \times 40 \mathrm{~cm})$ and two levels of mulching (mulch and no mulch). The experiment was laid out in a factorial randomized complete block design with three replications. The size of the unit plot was $4.0 \times 1.2 \mathrm{~m}$. The lettuce (cv. Green Wave) seeds were sown on 5 November 1999 and 15 November 2000 in poly bag (7 x $6 \mathrm{~cm}$ ) filled with a growing medium composed of 1:1 mixture of well-decomposed cowdung and sandy loam soil. Watering was done to polybag everyday with a fine-meshed water can. Twentyfive days old seedlings were transplanted on 01 December 1999 and 10 December 2000. Manures and fertilizers were applied @ cowdung 10 ton, Urea $300 \mathrm{~kg}$, TSP $200 \mathrm{~kg}$ and MP $150 \mathrm{~kg}$ per hectare. Half of the cowdung was applied during land preparation. The remaining cowdung, onethird urea, the entire amount of TSP and half of MP were applied during final land preparation. The rest of MP and urea was top-dressed in two equal splits at 7 days interval after transplanting in both the years. Irrigation along with other intercultural operations was done as and when needed. The crop was harvested at 54 and 52 days after sowing on 31 December 1999 and 07 January 2000 at the edible maturity stage. Data on plant height, canopy width, plant fresh weight and dry weight, leaf number and yield per plot at harvesting stage were collected from 10 randomly selected plants of each plot. The data were statistically analyzed and the treatment means were separated by Least Significant Difference (LSD) test at $5 \%$ level of probability. The economic analysis was also done to assess the profitability of lettuce.

\section{RESULTS AND DISCUSSION}

\section{Effects of plant spacing}

Plant spacing produced a significant influence on different yield attributes and yield of lettuce (Table 1). Plant height, canopy width, number of leaves, length of leaf, fresh and dry weight per plant increased as plant spacing increased. The widest spacing $(40 \times 40 \mathrm{~cm})$ produced the tallest plant (18.2 cm in 1999-00 and $18.5 \mathrm{~cm}$ in 2000-01), which was statistically at par with that recorded at medium spacing $(40 \times 30 \mathrm{~cm})$. There was no significant difference between $40 \times 30 \mathrm{~cm}$ and $40 \times$ 
$20 \mathrm{~cm}$ spacing treatment in respect of plant height. The results indicate that plant height increased with the increase in spacing. Wider spacing increased the average canopy width, number of leaves, length of leaf, which in turn produced maximum fresh weight $(315.0 \mathrm{~g}$ in $1999-00$ and $336.0 \mathrm{~g}$ in 2000-01) and dry weight ( $8.24 \mathrm{~g}$ in 1999 and $8.8 \mathrm{~g}$ in 2000 of the plant. This increase in vegetative growth at wider spacing might be due to less competition for nutrient, moisture and light among the plants.

Though plant height, canopy width, number of leaves, leaf length, fresh weight and dry weight per plant increased at wider spacing, the fresh yield of lettuce both in terms of fresh and dry weight decreased significantly in that spacing compared to other two spacings. The highest yield both in fresh weight (25.82 t/ha in 1999-00 and $27.10 \mathrm{t} / \mathrm{ha}$ in 2000-01) and dry weight (0.66 t/ha in 1999-00 and $0.7 \mathrm{t} / \mathrm{ha}$ in 2000-01) was obtained at closer spacing $(40 \times 20 \mathrm{~m})$ because of the increase in number of plants per unit area. The wider spacing $(40 \times 40 \mathrm{~cm})$ gave the lowest yield both in fresh weight (19.60 t/ha in 1999-00 and $21.00 \mathrm{t} / \mathrm{ha}$ in 2000-01) and dry weight (0.52 t/ha in 1999-00 and $0.56 \mathrm{t} / \mathrm{ha}$ in 2000-01). However, the yield obtained at closer spacing $(40 \times 20 \mathrm{~cm})$ did not differ significantly with the medium spacing $(40 \times 30 \mathrm{~cm})$. The significant increase in yield at closer spacing over wider spacing may solely be ascribed on the function of highest plant density per unit area of land.

\section{Effects of mulching}

Mulching had significant effect on yield attributes and yield of lettuce (Table 1). Plant height, canopy width, number of leaves per plant and leaf length increased due to mulching effect. Significantly the tallest plant (17.6 g in 1999-00) was produced when mulching was done but no significant effect was observed in 2000-01 in respect of plant height. Mulching increased the average canopy width and leaf length which in turn produced maximum fresh weight $(231.6 \mathrm{~g}$ and $235.7 \mathrm{~g}$ in 1999-00 and 2000-01, respectively) and dry weight (6.06 g in 1999-00 and $6.17 \mathrm{~g}$ in 2000-01) of the plant. Significantly higher fresh yield (27.5 t/ha in 1999-00 and 27.9 t/ha in 2000-01) as well as dry yield ( $0.72 \mathrm{~g}$ in $1999-00$ and $0.73 \mathrm{~g}$ in $2000-01)$ was recorded from mulch treated plot than that from control. Ashworth and Harrison (1983) also reported positive response to mulch in Chinese cabbage. The positive effect was probably due to the reduction of nutrients lost due to leaching, reaction of soil heat, and moisture conservation by mulching.

Table 1. Effect of plant spacing and mulching on yield and yield attributes of lettuce during the year of 1999 -'00 and 2000- '01

\begin{tabular}{|c|c|c|c|c|c|c|c|c|c|c|c|c|c|c|c|c|}
\hline \multirow[t]{2}{*}{ Treatment } & \multicolumn{2}{|c|}{$\begin{array}{l}\text { Plant } \\
\text { height } \\
(\mathrm{cm})\end{array}$} & \multicolumn{2}{|c|}{$\begin{array}{l}\text { Canopy } \\
\text { width } \\
(\mathrm{cm})\end{array}$} & \multicolumn{2}{|c|}{$\begin{array}{l}\text { No. of } \\
\text { leaves/ } \\
\text { plant }\end{array}$} & \multicolumn{2}{|c|}{$\begin{array}{l}\text { Maximum } \\
\text { length of } \\
\text { leaf }(\mathrm{cm})\end{array}$} & \multicolumn{2}{|c|}{$\begin{array}{c}\text { Fresh } \\
\text { weight/ } \\
\text { plant (g) }\end{array}$} & \multicolumn{2}{|c|}{$\begin{array}{c}\text { Dry } \\
\text { weight/ } \\
\text { plant (g) }\end{array}$} & \multicolumn{2}{|c|}{$\begin{array}{l}\text { Fresh } \\
\text { yield } \\
\text { (t/ha) }\end{array}$} & \multicolumn{2}{|c|}{$\begin{array}{c}\text { Dry yield } \\
\text { (t/ha) }\end{array}$} \\
\hline & $\begin{array}{c}1999 \\
-00\end{array}$ & $\begin{array}{c}2000- \\
01\end{array}$ & $\begin{array}{c}1999 \\
-00\end{array}$ & $\begin{array}{r}2000 \\
-01\end{array}$ & $\begin{array}{c}1999- \\
00\end{array}$ & $\begin{array}{c}2000- \\
01\end{array}$ & $\begin{array}{c}1999- \\
00\end{array}$ & $\begin{array}{c}2000- \\
01\end{array}$ & $\begin{array}{c}1999- \\
00\end{array}$ & $\begin{array}{c}2000- \\
01\end{array}$ & $\begin{array}{c}1999- \\
00\end{array}$ & $\begin{array}{c}2000 \\
-01\end{array}$ & $\begin{array}{c}1999- \\
00\end{array}$ & $\begin{array}{c}2000 \\
-01\end{array}$ & $\begin{array}{c}1999 \\
-00\end{array}$ & $\begin{array}{c}2000- \\
01\end{array}$ \\
\hline \multicolumn{17}{|l|}{ Spacing } \\
\hline $40 \times 20 \mathrm{~cm}$ & 16.3 & 16.4 & 27.9 & 28.3 & 28.1 & 28.5 & 18.3 & 18.7 & 200.5 & 217.1 & 5.33 & 5.78 & 25.06 & 27.10 & 0.66 & 0.70 \\
\hline $40 \times 30 \mathrm{~cm}$ & 17.4 & 17.6 & 29.6 & 30.1 & 29.2 & 29.4 & 19.3 & 19.8 & 288.5 & 310.2 & 7.48 & 8.04 & 24.04 & 25.82 & 0.62 & 0.65 \\
\hline $40 \times 40 \mathrm{~cm}$ & 18.2 & 18.5 & 31.2 & 31.6 & 29.9 & 30.1 & 20.4 & 20.9 & 315.2 & 336.3 & 8.24 & 8.80 & 19.60 & 21.00 & 0.52 & 0.56 \\
\hline $\operatorname{LSD}(0.05)$ & 1.2 & 1.5 & 1.9 & 1.7 & ns & ns & 1.3 & 1.2 & 49.8 & 31.3 & 0.47 & 0.79 & 1.05 & 1.40 & 0.11 & 0.10 \\
\hline CV (\%) & 10.93 & 10.68 & 8.69 & 8.52 & 9.87 & 8.99 & 7.56 & 7.54 & 9.35 & 9.64 & 9.25 & 9.14 & 7.69 & 7.53 & 4.26 & 4.57 \\
\hline \multicolumn{17}{|l|}{ Mulching } \\
\hline No mulch & 17.1 & 17.5 & 28.3 & 29.0 & 29.4 & 30.2 & 18.8 & 19.1 & 210.2 & 216.1 & 5.44 & 5.60 & 24.6 & 25.3 & 0.62 & 0.63 \\
\hline Mulch & 17.6 & 17.9 & 30.7 & 31.2 & 29.7 & 30.3 & 20.5 & 20.8 & 231.6 & 235.7 & 6.06 & 6.17 & 27.5 & 27.9 & 0.72 & 0.73 \\
\hline LSD (0.5) & 0.4 & ns & 2.1 & 1.9 & ns & ns & 1.3 & 1.5 & 19.3 & 12.5 & 0.49 & 0.31 & 1.9 & 1.7 & 0.1 & 0.1 \\
\hline CV (\%) & 10.93 & 10.68 & 8.69 & 8.52 & 9.87 & 8.99 & 7.56 & 7.54 & 9.35 & 9.64 & 9.25 & 9.14 & 7.69 & 7.53 & 4.26 & 4.57 \\
\hline
\end{tabular}

Note: "ns" indicates not significant at $5 \%$ level of probability 


\section{Combined effect of spacing and mulching}

Interaction effect of spacing and mulching on the yield and yield components was presented in Table 2. Among the parameters studied, plant height, fresh and dry weight per plant, fresh and dry yield per hectare was significantly affected due to interaction. The maximum fresh yield $(25.9 \mathrm{t} / \mathrm{ha}$ in 1999-00 and $28.3 \mathrm{t} / \mathrm{ha}$ in 2000-01) was observed in the closest spacing $(40 \times 20 \mathrm{~cm})$ with mulch which was statistically similar to medium spacing $(40 \times 30 \mathrm{~cm})$ with mulch. The lowest fresh yield (18.9 t/ha in 1999-00 and 19.8 t/ha in 2000-01) was found in wider spacing (40 x $40 \mathrm{~cm})$ without mulching. Mulching tended to increase each parameter including yield in each spacing but the increase in fresh yield was higher in $40 \times 20 \mathrm{~cm}$ spacing.

Table 2. Combined effect of plant spacing and mulching on yield and yield attributes of lettuce during the year of 1999-'00 and 2000-'01

\begin{tabular}{|c|c|c|c|c|c|c|c|c|c|c|c|c|c|c|c|c|c|}
\hline \multicolumn{2}{|c|}{$\begin{array}{c}\text { Treatment } \\
\text { combination }\end{array}$} & \multicolumn{2}{|c|}{$\begin{array}{c}\text { Plant } \\
\text { height }(\mathrm{cm})\end{array}$} & \multicolumn{2}{|c|}{$\begin{array}{c}\text { Canopy } \\
\text { width }(\mathrm{cm})\end{array}$} & \multicolumn{2}{|c|}{$\begin{array}{c}\text { No. of } \\
\text { leaves/plant }\end{array}$} & \multicolumn{2}{|c|}{$\begin{array}{l}\text { Maximum } \\
\text { length of } \\
\text { leaf }(\mathrm{cm})\end{array}$} & \multicolumn{2}{|c|}{$\begin{array}{c}\text { Fresh } \\
\text { weight/plant } \\
\text { (g) }\end{array}$} & \multicolumn{2}{|c|}{$\begin{array}{c}\text { Dry } \\
\text { weight/pla } \\
\text { nt (g) }\end{array}$} & \multicolumn{2}{|c|}{$\begin{array}{c}\text { Fresh yield } \\
\text { (t/ha) }\end{array}$} & \multicolumn{2}{|c|}{$\begin{array}{l}\text { Dry yield } \\
\text { (t/ha) }\end{array}$} \\
\hline Mulching & $\begin{array}{l}\text { Spacing } \\
\text { (cm) }\end{array}$ & $\begin{array}{c}1999 \\
-00\end{array}$ & $\begin{array}{c}2000 \\
-01\end{array}$ & $\begin{array}{c}1999 \\
-00\end{array}$ & $\begin{array}{r}2000 \\
-01\end{array}$ & $\begin{array}{c}1999- \\
00\end{array}$ & $\begin{array}{c}2000 \\
-01\end{array}$ & $\begin{array}{c}1999- \\
00\end{array}$ & $\begin{array}{c}2000 \\
-01\end{array}$ & $\begin{array}{r}1999 \\
-00\end{array}$ & $\begin{array}{c}2000 \\
-01\end{array}$ & $\begin{array}{l}199 \\
9-00\end{array}$ & $\begin{array}{c}2000 \\
-01\end{array}$ & $\begin{array}{c}1999- \\
00\end{array}$ & $\begin{array}{r}2000 \\
-01\end{array}$ & $\begin{array}{c}1999 \\
-00\end{array}$ & $\begin{array}{c}2000- \\
01\end{array}$ \\
\hline \multirow{4}{*}{$\begin{array}{l}\text { No } \\
\text { mulching }\end{array}$} & $40 \times 20$ & 15.7 & 16.9 & 25.2 & 25.8 & 26.4 & 26.8 & 16.7 & 17.2 & 180.0 & ) 190.1 & 5.04 & 5.30 & 22.2 & 22.8 & 0.56 & 0.57 \\
\hline & $40 \times 30$ & 18.1 & 17.3 & 28.2 & 28.6 & 29.5 & 30.0 & 18.1 & 18.64 & 253.2 & 258.0 & 7.15 & 7.51 & 21.1 & 21.5 & 0.54 & 0.54 \\
\hline & $40 \times 40$ & 20.8 & 20.2 & 31.6 & 31.3 & 30.0 & 30.5 & 18.9 & 19.5 & 301.1 & 318.0 & 7.87 & 8.31 & 18.9 & 19.8 & 0.48 & 0.52 \\
\hline & $40 \times 20$ & 16.8 & 18.1 & 29.9 & 30.2 & 27.9 & 28.4 & 17.9 & 18.4 & 215.0 & 226.8 & 5.71 & 6.02 & 25.9 & 28.3 & 0.69 & 0.73 \\
\hline \multirow[t]{2}{*}{ Mulching } & $40 \times 30$ & 19.3 & 18.5 & 30.8 & 30.9 & 30.1 & 30.5 & 18.4 & 19.1 & 311.2 & 328.1 & 8.07 & 8.51 & 25.2 & 27.4 & 0.66 & 0.72 \\
\hline & $40 \times 40$ & 22.0 & 21.5 & 31.6 & 32.2 & 32.2 & 32.8 & 21.5 & 22.2 & 340.1 & 350.6 & 9.03 & 9.30 & 21.3 & 21.9 & 0.54 & 0.57 \\
\hline LSD (0.5) & & 1.3 & 1.5 & ns & ns & ns & ns & ns & ns & 19.8 & 31.9 & 1.1 & 1.0 & 0.8 & 1.1 & 0.1 & 0.1 \\
\hline CV (\%) & & 10.93 & 10.68 & 8.69 & 8.52 & 9.87 & 8.99 & 7.56 & 7.54 & 9.35 & 9.64 & 9.25 & 9.14 & 7.69 & 7.53 & 4.26 & 4.57 \\
\hline
\end{tabular}

Note: "ns" indicates not significant at $5 \%$ level of probability

Table 3. Benefit-cost analysis on lettuce production in different spacing and mulching or without mulching (Two years' average data)

\begin{tabular}{ccccccc}
\hline Treatment combination & $\begin{array}{c}\text { Average } \\
\text { yield of } \\
\text { lettuce } \\
\text { (t/ha) }\end{array}$ & $\begin{array}{c}\text { Gross } \\
\text { return } \\
\text { (000 Tk.) }\end{array}$ & $\begin{array}{c}\text { Change in cost of * } \\
\text { seedlings and } \\
\text { mulch material } \\
\text { (000 Tk.) }\end{array}$ & $\begin{array}{c}\text { Change } \\
\text { in return* } \\
\text { (000 Tk.) }\end{array}$ & $\begin{array}{c}\text { Net Benefit- } \\
\text { cost ratio } \\
\text { (BCR) }\end{array}$ \\
\hline \hline \multirow{3}{*}{ No mulching } & $40 \times 20$ & 22.50 & 180.00 & 9.375 & 25.2 & 1.69 \\
& $40 \times 30$ & 21.30 & 170.00 & 3.125 & 15.2 & 3.86 \\
\hline \multirow{3}{*}{ Mulching } & $40 \times 40$ & 19.35 & 154.80 & 0.000 & - & - \\
\hline & $40 \times 20$ & 27.10 & 21.68 & 11.875 & 62.00 & 4.22 \\
& $40 \times 30$ & 26.27 & 210.16 & 5.625 & 55.36 & 8.84 \\
\hline
\end{tabular}

* Change in cost and change in return was calculated over $40 \times 40 \mathrm{~cm}$ spacing with no mulching treatment

Note: Price of Lettuce seedling $=$ Tk.15.00/100 seedlings

Product price $=$ Tk. $8.0 / \mathrm{kg}$

Rate of mulch material (rice straw) $=2.5 \mathrm{t} / \mathrm{ha}$

Price of rice straw $=$ Tk. $1.0 / \mathrm{kg}$

Net benefit cost ratio $=\frac{\text { Change in return }- \text { change in cost }}{}$

Change in cost

\section{Economics}

Table 3 showed that spacing of $40 \times 20 \mathrm{~cm}$ with mulching gave the gross return (Tk. 216.80 thousand per hectare) followed by mulching in 40 x 30 spacing (Tk. 210.16 thousand). But the 
highest benefit cost ratio (8.84) was obtained in $40 \times 30 \mathrm{~cm}$ with mulching followed by $40 \times 40 \mathrm{~cm}$ with mulching (6.22). The benefit cost ratio (4.22) from $40 \times 20 \mathrm{~cm}$ with mulching was less due to the involvement of high seedling cost. The results indicate that although the biological response of lettuce was observed due to mulching with $40 \times 20 \mathrm{~cm}$ spacing but the economic response was observed due to mulching with $40 \times 30 \mathrm{~cm}$ spacing.

The results of the present study suggest that lettuce cv, Green Wave can be grown in tropical areas at a plant spacing of $40 \times 30 \mathrm{~cm}$ with mulching done by dried rice straw for higher economic return.

\section{LITERATURE CITED}

Adu-Sandoke, A. 1980. The effect of spacing on four cultivars of lettuce. Department of Horticulture, University of Sci. and Tech., Ghana. p. 31.

Anonymous. 2000. ARC Training Report 2000. The 18 th Regional Training Course on Vegetable Production, Research and Extension, ARC-AVRDC, Thailand. 205p.

Ashworth, S. and Harrisson. 1983. Evaluation for mulches for use in the home garden. Hort Sci 18(2), 180-182.

AVRDC. 1990. Vegetable Production Training Manual. Shanhua, Tainan, Taiwan, Asian Vegetable Research and Development Centre (AVRDC). p. 184.

Benoit, F. and Ceustermans, N. 1996. Use of plastics in ecologically sound vegetable production in the open. Plasticulture 110, 35-43.

Bose, T. K. and Som, M. G. 1986. Vegetable Crops in India. Nawa Prakash, Calcutta. p. 692.

El-Shal, M., Kamar, M. F., Badr, H. M. and Wahba, R. S. 1986. The effect of seedling age and plant population on growth characteristics of lettuce. Alexandrea J Agric Res 31, 225-233.

Eyisok, D., Oten, D. S. and Ozzambak, E. 1996. Effect of plant distances on yield and quantity of lettuce and head lettuce. Vegetable cultivation Symposium, Harran University, May 1996. pp. 79-83.

Firoj, Z. A., Masud, M. A. T. and Rahman, M. A. 2000. Effect of spacing and mulching on the growth and yield of Chinese cabbage. Bangladesh J Agril Res 25(1), 95-102.

Knavel, D. E. and Mohr, H. C. 1967. Distribution of roots of different vegetable and pepper and polythene mulches. Proc Am Soc Hort Sci 91, 589-597.

Kobryn, J. 1987. Productivity of some crisp head lettuce cultivars in relation to sowing date and plant density in Autumn- Winter green house production. Eeszyty Nacekowe Akadimii Rolnictej VBin. Hugona Kollataj-wKrakowie Ogrednictwo. Warsaw Poland 210, 163-183.

Kuo, C. G. and Tsay, J. S. 1981. Physiological response of Chinese cabbage under high temperature. In "Chinese cabbage" (N. S. Talekar and T. D. Griggs, Eds), AVRDC, Shanhua, Tainan, Taiwan. pp. 217224.

Lippert, L. F., Takatori, F. H. and Whitting, F. L. 1964. Soil moisture under bands of petroleum mulches. Proc Am Soc Hort Sci 85, 541-546.

Rahman, M. T., Quasem, A., Alam, A. Saha, S. R. and Rashid, M. A. 1997. Perfomance of year round lettuce cultivars in Bangladesh. Bangladesh Hort 25 (1\&2), 57-60.

Rashid, M. M. 1999. Shabjibiggyan (In Bengali). Rashid publishing House. 84, old DOHS, Dhaka-1206. p. 497. 